Ekonomia - Wroclaw Economic Review 26/3 (2020)

Acta Universitatis Wratislaviensis

No 4008

https://doi.org/10.19195/2658-1310.26.3.6

Wioletta Nowak

ORCID: 0000-0002-9200-2972

University of Wrocław

wioletta.nowak@uwr.edu.pl

\title{
Inclusive growth in the fastest-growing Asian countries
}

Date of submission: 26.09.2020; date of acceptance: 10.10 .2020

JEL classification: O11, O53, I30, J40

Keywords: inclusive growth, inequality, poverty, working poor

\section{Abstract \\ Inclusive growth in the fastest-growing Asian countries}

The paper discusses the extent of inclusiveness of economic growth in the ten fastest-growing Asian countries between 2001 and 2019. It focuses on essential aspects of inclusiveness i.e. on poverty and inequality reduction and development of employment opportunities for poor people. The study is based on the data retrieved from the ILOSTAT and World Bank Database. In the twenty-first century, the fastest growing countries in Asia have significantly reduced poverty. However, the benefits of rapid economic growth in these countries have not been spread evenly. Income inequality has been steadily increasing in some Asian societies. Besides, economic growth in the fastest-growing countries in Asia has not been always accompanied by an increase in employment opportunities. Although unemployment is not a problem for the large part of the population in Asian countries, a lot of workers are still in extreme or moderate working poverty. Reasons behind the working poor in the fastest-growing Asian countries vary slightly from country to country but the most important are: jobless growth, high vulnerable employment in agriculture and a large part of the non-agricultural labour force working in the informal sector.

\section{Introduction}

Inclusive growth has been a widely-discussed issue in recent growth theory. However, there is no one definition of inclusive growth in the literature. Both developed and developing countries should be able to experience inclusive growth. But countries have to deal with quite opposite social, economic and demographic problems. Many developed countries have problems with overproduction of 
goods and services and an ageing society while developing countries have to deal with problems of young societies and a shortage of goods and services. As a result, different approaches to inclusive growth are needed regarding the country's level of development.

According to Mączyńska (2016) a harmonious socio-economic system must be inclusive. Inclusiveness means a combination of economic, social and ecological goals with optimizing the use of socio-economic potential and reduction to a minimum of waste of material resources and human capital. Rauniyar and Kanbur (2010) conclude that inclusive growth is coupled with equal opportunities. Moreover, it comprises economic, social, and institutional dimensions. Chang (2014) argues that inclusive growth is a growth which causes an increase in income (GDP per capita), poverty and inequality reduction, an increase in economic participation and promotion of the sustainable use of natural resources and climate protection.

Inclusive growth cannot be achieved only through social spending or other instruments of income redistribution to poorer households. It refers to an increase in opportunities and improvement in access to these opportunities. Growth is considered inclusive if the access increases either for all social groups, for the majority of the society (according to the World Bank) or for the poor (according to the Asian Development Bank). Opportunities can be increased for instance by job creation.

In the twenty-first century, several countries in Asia have recorded really high economic growth. They implemented different growth and development policies. Therefore, the main aim of the paper is answering the question whether economic growth in the fastest-growing Asian countries has been inclusive. The paper focuses on essential aspects of inclusiveness i.e. on poverty and income inequality reduction and development of employment opportunities for poor people in Asian countries.

The analysis covers ten countries (Bhutan, Cambodia, China, India, Lao PDR, Mongolia, Myanmar, Tajikistan, Turkmenistan, and Uzbekistan) in Asia which grew very fast over the period from 2001 to 2019. A simple statistical analysis of the data retrieved from the International Labour Organisation, the World Bank, and the Asian Development Bank databases has been applied. Besides, the paper was written based on a critical analysis of papers and reports regarding issues in economic growth and development in Asian countries.

There are a lot of studies on economic growth and development in Asian countries. Issues in economic growth in Asia were discussed for instance by Nguyen (2017), Nowak (2017, 2018, 2019), Rock (2018), Chesters (2019), and also in many of the World Bank's and the Asian Development Bank's reports.

The main contribution of the paper is a comparison of the extent of inclusiveness of economic growth in the ten fastest-growing Asian countries between 2001 and 2019. 


\section{The fastest-growing Asian countries in the years 2001-2019}

Over the period from 2001 to 2019, several Asian countries recorded high GDP growth rates. The highest economic growth was observed in Myanmar and China. The average annual GDP growth rate in these two countries was more than $9 \%$. Slightly lower economic growth was recorded in Turkmenistan, Tajikistan, and Cambodia. What's more, the annual GDP growth rate in Bhutan, Lao PDR, and Mongolia averaged over 7\%. The economies of Uzbekistan and India had average annual GDP growth rates of over $6.5 \%$. The countries experienced rapid GDP growth after the 2008 financial crisis, too (Table 1).

Table 1. Average annual GDP and GDP per capita growth in Asia, 2001-2019

\begin{tabular}{|l|c|c|c|c|}
\hline \multirow{2}{*}{ Country } & \multicolumn{2}{|c|}{ GDP growth (\%) } & \multicolumn{2}{c|}{ GDP per capita growth (\%) } \\
\cline { 2 - 5 } & 2001-2019 & 2009-2019 & 2001-2019 & 2009-2019 \\
\hline Myanmar & 9.3 & 7.1 & 8.5 & 6.3 \\
\hline China & 9.0 & 7.8 & 8.4 & 7.3 \\
\hline Turkmenistan* & 8.2 & 8.7 & 6.7 & 6.8 \\
\hline Tajikistan & 7.6 & 6.7 & 5.4 & 4.3 \\
\hline Cambodia & 7.6 & 6.4 & 5.8 & 4.7 \\
\hline Bhutan* & 7.3 & 6.2 & 5.9 & 5.0 \\
\hline Lao PDR & 7.1 & 7.3 & 5.4 & 5.6 \\
\hline Mongolia & 7.1 & 6.7 & 5.4 & 4.8 \\
\hline Uzbekistan & 6.7 & 6.8 & 5.0 & 4.8 \\
\hline India & 6.6 & 6.8 & 5.2 & 5.6 \\
\hline
\end{tabular}

* Available data for Turkmenistan and Bhutan covered the years 2001-2018. Hence, GDP growth rates in these countries were calculated for 2001-2018 and 2009-2018, respectively.

Source: own calculations based on WBOD (2020).

In the years 2001-2019, GDP per capita growth in the group of the fastest-growing Asian countries ranged from about 5\% in Uzbekistan and India to more than $8 \%$ in Myanmar and China. Lao PDR, Mongolia, and Tajikistan recorded almost the same annual GDP per capita growth. After 2008, the highest GDP per capita growth rates were recorded in China, followed by Turkmenistan and Myanmar.

The fastest-growing Asian countries implemented different growth strategies. The main drivers of economic growth in these countries are presented in Table 2. 
Table 2. Main drivers of economic growth in Asian countries in the 21st century

\begin{tabular}{|l|l|}
\hline Bhutan & $\begin{array}{l}\text { Development of hydropower generation capacity and exports of electricity to } \\
\text { India. }\end{array}$ \\
\hline Cambodia & Exports of clothing, footwear, precious stones, timber, and rubber. \\
\hline China & $\begin{array}{l}\text { Public investment in infrastructure and development of export-oriented } \\
\text { production. }\end{array}$ \\
\hline India & $\begin{array}{l}\text { Services (computer software sector, computer services, ITC, business and } \\
\text { financial services). }\end{array}$ \\
\hline Lao PDR & $\begin{array}{l}\text { Exploitation of natural resources, investment in mining and hydropower, } \\
\text { construction, and tourism-related services. }\end{array}$ \\
\hline Mongolia & Development of mining and mineral exports (oil, precious metals, copper). \\
\hline Myanmar & $\begin{array}{l}\text { Exploitation of natural resources, development of labour intensive sectors } \\
\text { (food processing, textiles, and clothing industries). }\end{array}$ \\
\hline Tajikistan & Exports of raw materials (aluminium, gold, and cotton). \\
\hline Turkmenistan & Hydrocarbons and construction. \\
\hline Uzbekistan & $\begin{array}{l}\text { Exports of raw materials (natural gas and gold) and large public investment } \\
\text { in the mining industry, hydroelectric power plants, road infrastructure, and } \\
\text { housing. }\end{array}$ \\
\hline
\end{tabular}

Source: own elaboration.

In the twenty-first century, economic growth in a few analysed Asian countries (Mongolia, Tajikistan, Turkmenistan, and Uzbekistan) has been generated through extractive sectors. Exploitation of natural resources played an important role also in the economies of Lao PDR and Myanmar. Development of the hydropower sector was the main driver of economic growth in Bhutan. On the other hand, the structural transformation and trade and investment-led growth were observed in Cambodia. China intensively invested in infrastructure and developed its labour-intensive, export-oriented sectors. Labour-intensive industries were developed in Myanmar, too. India experienced services-driven growth. Among the analysed countries, Bhutan and Turkmenistan have followed a public-sector-led development path.

Between 2001 and 2019, the fastest-growing countries in Asia significantly reduced poverty. However, economic growth in these countries has not always coincided with an increase in employment opportunities. Countries recorded job creation in manufacturing and services but extractive sectors which dominated in several Asian economies generated little employment. As a result, still the majority of jobs in the fastest-growing Asian countries is low-productivity and low-paid in agriculture, household enterprises, and small firms. 


\section{Poverty and working poor in Asian countries}

The lowest poverty headcount ratio at national level is in China. In a population of over 1.4 billion, $1.7 \%$ live below the national poverty line and less than $1 \%$ below an absolute international poverty line of 1.90 US\$ a day at 2011 purchasing power parity (PPP). An estimated $8.2 \%$ of households in Bhutan are classified as poor regarding the national poverty line and $1.5 \%$ of Bhutanese are subsistence poor. A relatively low share of the population below the poverty line has been recorded in Uzbekistan and Cambodia. In contrast, about $28 \%$ of the population live below the national poverty threshold in Mongolia and Tajikistan. In the 21st century, the poverty headcount ratio at national level declined the most in Tajikistan and Cambodia. Taking into account the absolute international poverty line, nearly one fifth of the population in Lao PDR and India have been living below 1.90 US\$ a day (Table 3).

Table 3. Measures of poverty in Asian countries

\begin{tabular}{|l|c|c|c|c|}
\hline \multirow{2}{*}{ Country } & \multicolumn{2}{|c|}{$\begin{array}{c}\text { Share of population below the } \\
\text { national poverty line (\%) }\end{array}$} & \multicolumn{2}{c|}{$\begin{array}{c}\text { Poverty headcount ratio at \$1.90 } \\
\text { a day (2011 PPP) (\%) }\end{array}$} \\
\cline { 2 - 5 } & 2002 & 2018 & 2002 & 2018 \\
\hline Bhutan & $25.3(2001)$ & $8.2(2016)$ & $17.6(2003)$ & $1.5(2017)$ \\
\hline Cambodia & 35.9 & 12.9 & n.a. & n.a. \\
\hline China & 4.6 & 1.7 & 31.7 & $0.5(2016)$ \\
\hline India & 26.1 & n.a. & $38.2(2004)$ & $21.2(2011)$ \\
\hline Lao PDR & 38.6 & $23.2(2012)$ & 33.8 & $22.8(2012)$ \\
\hline Mongolia & 35.6 & 28.4 & 9.7 & 0.5 \\
\hline Myanmar & 22.9 & $24.8(2017)$ & n.a. & $2.0(2017)$ \\
\hline Tajikistan & $56.6(2003)$ & 27.4 & $30.8(2003)$ & $4.8(2015)$ \\
\hline Turkmenistan & 29.9 & n.a. & n.a. & n.a. \\
\hline Uzbekistan & $27.5(2000)$ & 11.4 & $62.1(2003)$ & n.a. \\
\hline
\end{tabular}

Note: n.a. denotes data not available from 2012 to 2019 .

Source: ADB (2020).

In general, unemployment is not an option for the large part of the population in Asian countries. The unemployment rate is very low in countries such as Cambodia and Myanmar (less than 1\%). The average unemployment rate remains also low in Tajikistan, Bhutan, and Turkmenistan. On the other hand, the highest unemployment rate was recorded in Mongolia (10\% in 2019), Uzbekistan $(9.3 \%$ in 2018), and Lao PDR (9.4\% in 2017). Between 2001 and 2019, unemployment slightly decreased only in Cambodia, Myanmar, and Tajikistan (Table 4). 
Table 4. Unemployment and working poverty rates in Asian countries

\begin{tabular}{|c|c|c|c|c|}
\hline \multirow{2}{*}{ Country } & \multicolumn{2}{|c|}{$\begin{array}{c}\text { Unemployment, total } \\
\text { \% of total labour force) }\end{array}$} & \multicolumn{2}{c|}{$\begin{array}{c}\text { Percentage of employed living } \\
\text { below US\$ 3.20 PPP (\%) }\end{array}$} \\
\cline { 2 - 5 } & 2001 & 2019 & 2001 & 2019 \\
\hline Bhutan & 1.9 & 2.7 & 51.2 & 11.2 \\
\hline Cambodia & 2.1 & $0.1(2017)$ & 90.9 & 36.9 \\
\hline China & 3.6 & 5.2 & 62.3 & 5.2 \\
\hline India & 2.9 & $5.3(2018)$ & 77.3 & 42.4 \\
\hline Lao PDR & 5.0 & $9.4(2017)$ & 74.3 & 35.6 \\
\hline Mongolia & 4.6 & 10.0 & 37.2 & 2.0 \\
\hline Myanmar & 1.2 & 0.5 & 55.8 & 17.1 \\
\hline Tajikistan & $2.3 *$ & $2.1 *$ & 77.6 & 15.9 \\
\hline Turkmenistan & 2.6 & 3.9 & 65.3 & 14.4 \\
\hline Uzbekistan & 0.4 & $9.3(2018)$ & 81.1 & 37.2 \\
\hline
\end{tabular}

* refers to registered unemployment.

Source: ILOSTAT (2020).

A lot of workers in the fastest-growing Asian countries are still in extreme or moderate working poverty. ${ }^{1}$ Although people are employed, they are not able to lift themselves and their families above the poverty threshold. For instance, in 2019 , more than $40 \%$ of the Indian total employment and over one third of workers in Uzbekistan, Cambodia, and Lao PDR lived below US\$ 3.20 PPP a day (Table 4).

In 2019 , the extreme working poverty rate stood at nearly $20 \%$ in Uzbekistan and about $10 \%$ in India and Lao PDR. What's more, about $8 \%$ of the total employment in Cambodia and Turkmenistan were classified as extreme working poor. On the other hand, extreme working poverty has been almost eradicated in Mongolia and China. It was relatively low in Bhutan (1.3\%), Myanmar (2.7\%), and Tajikistan (3.8\%).

Over the period from 2001 to 2019, the biggest reduction in extreme and moderate working poverty was recorded in Tajikistan (61.7 percentage points) and China (57.1 percentage points). Moreover, the percentage of employed living below US\$ 3.20 PPP a day was halved in Cambodia and Turkmenistan. It is worth noting that Cambodia has seen the most significant decline (61.1 percentage

${ }^{1}$ In 2019, The International Labour Organisation distinguished the following economic classes: extreme working poor: per capita household consumption below $\$ 1.90$ a day at PPP in 2011; moderate working poor: between $\$ 1.90$ and $\$ 3.20$; near poor: between $\$ 3.20$ and $\$ 5.50$, and developing middle class and above: $\$ 5.50$ or more a day (ILOSTAT, 2020).

Ekonomia - Wroclaw Economic Review 26/3, 2020

(C) for this edition by CNS 
points) in extreme working poverty. Changes in employment distribution by economic class in Asian countries are presented in Figure 1.

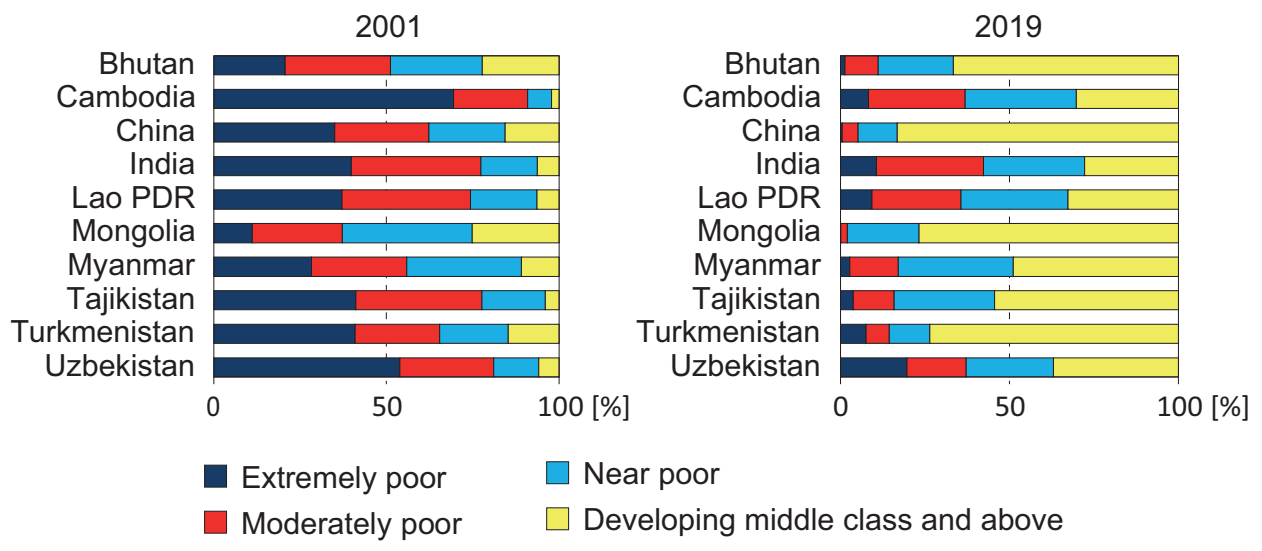

Figure 1. Employment distribution by economic class in the fastest-growing Asian countries, 2001 and 2019

Source: own work based on ILOSTAT (2020).

The reasons behind the working poor in the fastest-growing Asian countries vary slightly from country to country. However, they have common features. First of all, in a few countries, employment opportunities have not kept up with rapid economic growth. Sectors which were the main drivers of economic growth didn't create many new jobs. For instance, in Bhutan the hydropower sector employs less than $1 \%$ of the Bhutanese labour force. Similarly, in Turkmenistan the hydrocarbon sector provides employment to about $2 \%$ of the labour force. The services and industrial sector contribute over $80 \%$ in overall gross added value in Bhutan, India, Lao PDR, and Tajikistan. However, agriculture is the single largest employment generator in these countries. India has a services-driven economy but the contribution of services to employment is lower than agriculture. In 2019, agriculture accounted for more than half of the total employment in Lao PDR and Bhutan and nearly $50 \%$ in Myanmar. Besides, the agricultural sector employs more than $40 \%$ of the total working population in Tajikistan and India (WBOD, 2020).

A large proportion of workers in the fastest-growing Asian countries still lack job security, written contracts, and income stability. Most people have jobs that are less well-paid or below their skill levels (ILO, 2019). In general, labour markets in Asia need reforms to decrease the high rate of under-employment.

In a few Asian countries vulnerable employment ${ }^{2}$ has remained at a high level. In 2019, it accounted for around 80\% in Lao PDR and over 70\% in India

2 The employed group is broken down into two subgroups: wage and salaried workers (employees) and self-employed workers. The self-employed group covers employers (self-employed workers with employees), own-account workers (self-employed workers without employees), and 
and Bhutan. Moreover, own-account workers and contributing family workers together represented over half of total employment in Myanmar and Cambodia. It is worth noting that self-employment in Asian countries is often associated with poverty. People are forced to be self-employed because they have no access to wage employment. On the other hand, employees accounted for nearly $70 \%$ in Turkmenistan. This is because the Turkmen economy and formal labour market have been dominated by the public sector and state-owned monopolies. In 2019, wage and salaried workers stood at $50 \%$ or more of total employment in four more countries (Tajikistan, Uzbekistan, China, and Mongolia). This category of employment is associated with greater income security and better working conditions (Table 5).

Table 5. Employment in Asian countries by status in employment, 2001 and 2019 (\%)

\begin{tabular}{|l|c|c|c|c|c|c|c|c|}
\hline \multirow{2}{*}{ Country } & \multicolumn{2}{|c|}{ Employees } & \multicolumn{2}{c|}{ Employers } & \multicolumn{2}{c|}{$\begin{array}{c}\text { Own account } \\
\text { workers }\end{array}$} & \multicolumn{2}{c|}{$\begin{array}{c}\text { Contributing fam- } \\
\text { ily workers }\end{array}$} \\
\cline { 2 - 9 } & 2001 & 2019 & 2001 & 2019 & 2001 & 2019 & 2001 & 2019 \\
\hline Bhutan & 25.3 & 28.4 & 0.1 & 0.1 & 25.4 & 39.2 & 49.1 & 32.3 \\
\hline Cambodia & 14.9 & 49.6 & 0.3 & 0.1 & 47.4 & 45.7 & 37.4 & 4.6 \\
\hline China & 38.6 & 53.3 & 1.4 & 1.4 & 35.3 & 32 & 24.7 & 13.4 \\
\hline India & 15.3 & 23.7 & 1.0 & 2.0 & 65.2 & 62.1 & 18.4 & 12.1 \\
\hline Lao PDR & 11.7 & 19.4 & 0.3 & 0.6 & 53.4 & 53.1 & 34.6 & 27.0 \\
\hline Mongolia & 42.3 & 50.6 & 1.3 & 0.9 & 32.7 & 45.8 & 23.7 & 2.7 \\
\hline Myanmar & 26.1 & 37.9 & 2.3 & 3.0 & 34.4 & 35.7 & 37.3 & 23.4 \\
\hline Tajikistan & 52.7 & 57.1 & 1.1 & 1.2 & 18.2 & 17.6 & 28.0 & 24.1 \\
\hline Turkmenistan & 69.7 & 72.9 & 1.9 & 1.8 & 22.9 & 21.4 & 5.5 & 3.8 \\
\hline Uzbekistan & 50.7 & 56.6 & 1.2 & 1.4 & 34.1 & 33.5 & 14.0 & 8.5 \\
\hline
\end{tabular}

Source: ILOSTAT (2020).

Between 2001 and 2019, the biggest shifts in employment categories were observed in Cambodia, China, and Myanmar. Vulnerable employment in Cambodia declined by 34.5 percentage points. China and Myanmar reduced it by 14.6 and 12.6 percentage points, respectively. Among the analysed countries, Cambodia made the largest progress in reduction of unpaid family work. Overall, in the fastest-growing Asian countries, the dominant trend in the employment category shares in total employment is the increase in employees. The category own account workers increased the most in Bhutan and Mongolia.

Rapid economic growth in Asian countries was accompanied by structural transformation. Employment has been moved away from agriculture into sectors with higher added value as a result. However, the share of agriculture in total em-

contributing family workers. Own-account workers and contributing family workers are called vulnerable employment. 
ployment still remains high in Lao PDR (62.4\% in 2019), Bhutan (55.3\%), Myanmar (48.9\%), Tajikistan (44.9\%), and India (42.4\%).

In the analysed Asian countries a large part of the non-agricultural labour force have been still working in the informal sector. Among the analysed countries, only Turkmenistan and Mongolia recorded relatively low percentages of informal workers in total non-agricultural employment in 2018 (Table 6).

Table 6. Percentage of informal workers in total non-agricultural employment, 2018 (\%)

\begin{tabular}{|l|c|c|c|}
\hline \multicolumn{1}{|c|}{ Country } & Percentage & Country & Percentage \\
\hline Bhutan & $80(2014)$ & Mongolia & 30.9 \\
\hline Cambodia & $90(2016)$ & Myanmar & 78.9 \\
\hline China & 53.5 & Tajikistan & 70.5 \\
\hline India & 80.3 & Turkmenistan & 18 (men), 29 (women) \\
\hline Lao PDR & $75.5(2017)$ & Uzbekistan & 60.0 \\
\hline
\end{tabular}

Source: WBOD (2020) and ILOSTAT (2020). Data for Turkmenistan based on VNRT (2019).

\section{Income inequality and inequality in opportunities}

The fastest-growing Asian countries have improved living standards and greatly reduced poverty. However, in most of them economic growth and poverty alleviation have been accompanied by rising income inequality. The income distribution in the analysed countries was affected primarily by globalisation, technological progress, and market-oriented reforms.

According to HDR (2019), China, Myanmar, Bhutan, and Lao PDR are countries with high income inequality while Mongolia, Tajikistan, and India are more equal countries in terms of income (Table 7).

Table 7. Indices of income inequality, 2010-2017

\begin{tabular}{|l|c|c|c|}
\hline \multirow{2}{*}{\multicolumn{1}{|c|}{ Country }} & \multirow{2}{*}{ Gini coefficient } & \multicolumn{2}{c|}{ Income share (in \%) held by } \\
\cline { 3 - 4 } & & Richest $10 \%$ & Poorest $40 \%$ \\
\hline Bhutan & 37.4 & 27.9 & 17.5 \\
\hline China & 38.6 & 29.4 & 17.0 \\
\hline India & 35.7 & 30.1 & 19.8 \\
\hline Lao PDR & 36.4 & 29.8 & 19.1 \\
\hline Mongolia & 32.3 & 25.6 & 20.4 \\
\hline Myanmar & 38.1 & 31.7 & 18.6 \\
\hline Tajikistan & 34.0 & 26.4 & 19.4 \\
\hline
\end{tabular}

Note: Data refer to the most recent year available during the period specified and they do not include Cambodia, Turkmenistan, and Uzbekistan.

Source: HDR (2019). 
The UNESCAP (2018) report shows that the average Gini coefficient for 2010-2014 was about 43 for Turkmenistan, 40 for Uzbekistan, and 32 for Cambodia. Besides, in the 21 st century, income inequality measured by the Gini coefficient rose the most in China, Uzbekistan, and India. In China, the wealth share held by the top 1\% doubled between 1995 and 2015. Inequality declined in Mongolia, Cambodia, and Bhutan.

The transition from agriculture-based Asian societies to manufacturing- and services-driven ones has led to increases in income for people who were engaged in activities characterised by faster increases in labour productivity. The highest labour income inequality has been observed in India. In 2017, the top earning $10 \%$ received $69.4 \%$ of total pay, the next decile received $13.5 \%$, whereas the remaining $80 \%$ of Indian workers received $17.1 \%$. A big share of labour income for the top of the distribution is recorded in Lao PDR. In this country labour income earned by the top $20 \%$ accounted for $67.7 \%$ of total pay in 2017 . Myanmar, Turkmenistan, and Uzbekistan are countries with less unequal distributions of labour income (Figure 2).

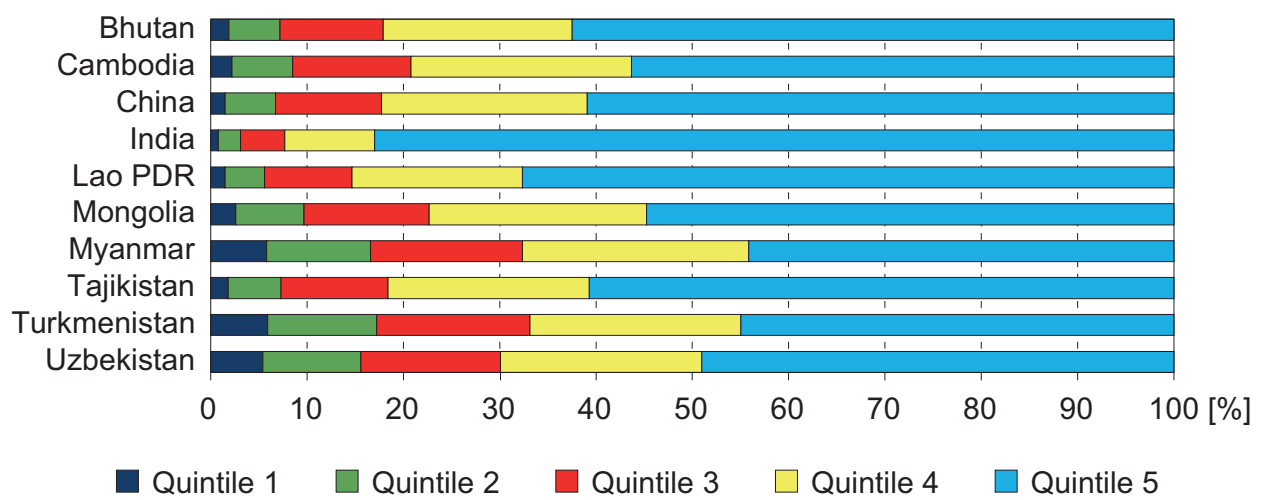

Figure 2. Labour income distribution by quintile, 2017

Source: ILOSTAT (2020).

Between 2004 and 2017, the degree of inequality in labour income decreased the most in Cambodia and Lao PDR. On the other hand, neither China nor India registered a decline in labour income inequality (ILOSTAT, 2020).

Some level in income inequality is acceptable and expected because it reflects differences in levels of individual effort and talent. However, there is no excuse for inequality in access to core opportunities (access to education, health care, full-time employment, finance, clean energy, and water and sanitation) which is a key factor in widening income inequality. Inequality of opportunity reflects often institutional weaknesses and social exclusion. Among the fastest growing countries, Cambodia, Lao PDR, and Myanmar stand out as countries with the highest inequality in access to core opportunities. Conversely, Tajikistan, Turkmenistan, 
and Uzbekistan have on average significantly lower inequalities in access to the same opportunities (UNESCAP, 2018).

It is worth noting that before 1991, inequality in access to core opportunities in the former Soviet Republics was low, due to the strong provision of universal social protection and basic public services. After independence, Tajikistan, Turkmenistan, and Uzbekistan experienced negative economic growth and an increase in income inequality. Public spending was a key tool used by governments to support the well-being of low-income households. Among these countries, Turkmenistan decided to increase social protection to the greatest extent. The country provided large subsidies to its citizens in the years 1991-2014. Petroleum products, some health-care services, electricity, gas, heating, and water were provided at very low cost. Moreover, subsides were given to public transport, certain foods, medicines, housing, telephones, pre-schools, and several other services. In 2014, the Turkmen government decided to reform policy of subsidies and liberalise prices on regulated goods and services. Free electricity, gas, and water were ended in January 2019.

Income inequality is a complex phenomenon and depends on many various factors. More equal access to core opportunities and reduction in labour income inequality certainly lead to a decrease in income inequality. However, in some countries high income inequality may be maintained despite satisfying these conditions. For instance, Turkmenistan and Uzbekistan are countries with both lower labour income inequality and inequality in core opportunities but higher income inequality compared to other Asian countries.

\section{Conclusions}

Several Asian countries have experienced remarkable economic growth and transformation in the twenty-first century. Millions of people have taken advantage of opportunities to improve their standard of living. However, the benefits of rapid economic growth have not been spread evenly. Income inequality has been steadily increasing in some Asian societies. The most unequal countries have been the following: Turkmenistan, Uzbekistan, China, and Myanmar. Among the fastest-growing Asian countries, Mongolia, Cambodia, and Bhutan have recorded a decline in income inequality.

After decades of fast economic growth, Asian countries still face extreme poverty among employees. Over 35\% of workers in India, Cambodia, Uzbekistan, and Lao PDR have been living below US\$ 3.20 PPP a day. Reasons behind the working poor in the fastest growing Asian countries vary slightly from country to country but the most important are: jobless growth, high vulnerable employment in agriculture and a large part of the non-agricultural labour force working in the informal sector. 
Inclusive growth still should be at the heart of development strategies in the fastest-developing Asian countries.

\section{References}

ADB (2020). Asian Development Bank. Basic Statistics. Date of access: 20.09.2020, https://www. adb.org/publications/basic-statistics.

Chang, C. (2014). What is "inclusive growth"? CAFOD Discussion Paper, CAFOD, London. Date of access: 20.09.2020, https://cafod.org.uk/content/download/17223/133621/version/4/file/Inclusive $\% 20$ Growth $\% 20$ full $\% 20$ paper.pdf.

Chesters, J. (2019). Economic growth, wealth and wealth inequality in Asia before, during and after the global financial crisis. Asian Journal of Social Science, 47(4/5), 459-483.

HDR (2019). Beyond income, beyond averages, beyond today: Inequalities in human development in the 21st century. Human Development Report. Date of access: 20.09.2020, http://hdr.undp. org/sites/default/files/hdr2019.pdf.

ILOSTAT (2020). Statistics on the working poor. Date of access: 13.09.2020, https://ilostat.ilo.org/ topics/working-poor/.

Mączyńska, E. (2016). Gospodarka inkluzywna - wymiar samorzadowy. Date of access: 3.09.2020, https://www.bgk.pl/files/public/Pliki/news/Konferencje_BGK/XII_Konferencja_BGK_dla_ JST/Materialy_konferencyjne/Elzbieta_Maczynska_Gospodarka_inkluzywna_-_wymiar_ samorzadowy.pdf.

Nguyen, A.T. (2017). Impacts of macroeconomic indicators on economic growth in Southeast Asia: A panel data analysis. Journal of Economics and Business Research, 23(2), 111-128.

Nowak, W. (2017). Economic development in Asian least developed countries. In M. Cingula, M. Przygoda and K. Detelj (eds.), Economic and Social Development (Book of Proceedings), 23rd International Scientific Conference on Economic and Social Development, Madrid, 1516 September 2017. Varazdin Development and Entrepreneurship Agency, Varazdin, Croatia; University North, Koprivnica, Croatia; Faculty of Management University of Warsaw, Warsaw, Poland, 128-137.

Nowak, W. (2018). Development trends in least developed countries. In N. Grünwald and M. Zakrzewska (eds.), Proceedings of the $5^{\text {th }}$ International Conference "Modern Economics", 14-16 May 2018, University of Vigo. Robert-Schmidt-Institut, University of Wismar, Germany, 41-48.

Nowak, W. (2019). Wyzwania rozwojowe w najszybciej rozwijających się krajach azjatyckich. Ekonomia - Wroclaw Economic Review, 25(2), 21-36.

Rauniyar, G., Kanbur, R. (2010). Inclusive growth and inclusive development: A review of synthesis of Asian Development Bank literature. Journal of the Asia Pacific Economy, 15(4), 455-469.

Rock, M.T. (2018). The last fifty years. Development strategy and development performance in Southeast Asia. Journal of Southeast Asian Economies, 35(1), 39-49.

UNESCAP (2018). Inequality in Asia and the Pacific in the era of the 2030 Agenda for Sustainable Development. United Nations Economic and Social Commission for Asia and the Pacific. Date of access: 25.08.2020, https://www.unescap.org/commission/74/files/Inequality-L.pdf.

WBOD (2020). World Bank Open Data. Date of access: 20.09.2020, https://data.worldbank.org.

VNRT (2019). Voluntary National Review of Turkmenistan. Empowering people and ensuring inclusiveness and equality. Turkmen State Publishing Service. Date of access: 12.02.2020, https:// sustainabledevelopment.un.org/content/documents/24723Voluntary_National_Review_of_ Turkmenistan.pdf.

Ekonomia - Wroclaw Economic Review 26/3, 2020

(C) for this edition by CNS 